\title{
Uji Fitokimia Secara Kualitatif Pada Buah dan Ekstrak Air Buah Mangrove
}

\section{[Qualitative Phytochemical Tests on Mangrove Fruit and Fruit Water Extracts]

\author{
Husnul Khatimah Ramli ${ }^{1}$, Tatty Yuniarti ${ }^{2}$, Noor Pitto Sari Nio Lita ${ }^{2}$, \\ Yuliati Hotmauli Sipahutar ${ }^{3}$
}

\author{
${ }^{1}$ Program Studi Pemanfaatan Sumberdaya Perikanan, Program Pasca Sarjana, \\ ${ }^{2}$ Program Studi Penyuluhan Perikanan, \\ ${ }^{3}$ Program Studi Teknologi Pengolahan Hasil Perikanan, \\ Politeknik Ahli Usaha Perikanan, JI. AUP, Pasar. Minggu, Jakarta Selatan,12520
}

\begin{abstract}
Abstrak
Mangrove diketahui mempunyai komponen fitokimia yang mempunyai kemampuan bioaktif. Uji kualitatif komponen fitokimia diperlukan untuk screening awal eksplorasi komponen bioaktif tanaman. Air adalah pelarut komponen fitokimia yang relatif aman dan tidak polutif. Penelitian ini dilakukan untuk membandingkan komponen fitokimia yang terdapat pada buah mangrove sebelum dan sesudah diekstraksi menggunakan pelarut air. Jenis buah mangrove yang digunakan adalah Rhizophora mucronata, Rhizophora apiculata, dan Avicennia marina. Pembuatan ekstrak buah mangrove dilakukan dengan menggunakan pelarut akuades, dengan proses pecacahan, pembilasan dengan asam sitrat $0,5 \%$, perendaman akuades, pengeringan, sonikasi, dan penyaringan filtrat. Hasil uji fitokimia (kualitatif) menunjukkan kandungan fitokimia yang terdapat pada ekstrak buah Rhizophora mucronata adalah saponin dan steroid, sedangkan kandungan yang terdapat pada ekstrak buah Rizophora apiculata dan Avicennia marina adalah tanin, saponin, dan steroid. Kesimpulan dari penelitian ini adalah pelarut akuades dan pembilasan dengan asam sitrat 0,5\% dapat melarutkan komponen fitokimia tanin, saponin dan steroid dalam buah mangrove.
\end{abstract}

Kata kunci : air; asam sitrat; ekstraksi

\section{Abstract}

Mangroves are known to have phytochemical components that have bioactive abilities. Qualitative phytochemical component testing is required for initial screening for bioactive components of plants. Water is a solvent of phytochemical components that is relatively safe and not pollutant. This research was conducted to compare the phytochemical components found in mangroves before and after extraction using water solvents. The types of mangroves used are Rhizophora mucronata, Rhizophora apiculata, and Avicennia marina. Making mangrove fruit extracts is done using distilled water, with the process of shredding, rinsing with $0.5 \%$ citric acid, soaking distilled water, drying, sonication, and filtration filtration. Phytochemical test results (qualitative) showed that the phytochemical content contained in Rhizophora mucronata fruit extract were saponins and steroids, while the content contained in Rizophora apiculata and Avicennia marina fruit extracts were tannins, saponins, and steroids. The conclusion of this research is that distilled water and flushing with $0.5 \%$ citric acid can dissolve phytochemical components of tannins, saponins and steroids in mangroves.

Keywords: citric acid; extraction; water

Penulis Korespondensi

Tatty Yuniarti | tatty.yuni@gmail.com 


\section{PENDAHULUAN}

Mangrove merupakan ekosistem di wilayah pesisir yang mempunyai manfaat ekologis dan manfaat ekonomis penting, baik yang berasal dari kayu, biji, maupun buah. Batang/pohon mangrove dimanfaatkan sebagai kayu bakar dan obat-obatan. Sedangkan buah maupun propagul mangrove dapat diolah menjadi beragam makanan (A'in, Suryanti, dan Sulardiono 2018). Pada saat musim panen, buah mangrove sangat berlimpah dan dianggap sebagai "sampah" lingkungan sehingga pengolahan buah mangrove menjadi produk makanan, selain dapat mengurangi beban degradasi lingkungan, juga akan semakin mempertajam fungsi dan kegunaan mangrove baik secara ekologis maupun ekonomi ( $\mathrm{Mu}$ et al. 2012). Mangrove telah dimanfaatkan oleh masyarakat pesisir untuk pengobatan alamiah. Rhizophora mucronata adalah salah satu spesies mangrove yang mempunyai efek sebagai antibakteri, antioksidan dan anti diare (Sudjarwo, Mahmiah, dan Hukmiyah OM 2017). Pemanfaatan mangrove untuk pengobatan, karena adanya komponen fitokimia baik pada buah, daun, batang dan akar mangrove. Rhizophora apiculata bermanfaat sebagai anti diare, obat mual, muntah, antiviral dan hypoglikemik. Pada bagian kulit batang Rhizophora apiculata menghasilkan tanin yang digunakan sebagai sumber antioksidan alami (Khairun dan Desty 2018).

Berbagai jenis mangrove telah diteliti komponen fitokimia dan kemampuan bioaktifnya. Tanaman mangrove Rhizophora sp. mempunyai komponen fitokimia seperti tanin, saponin, terpenoid, alkaloid, dan flavonoid berpotensi dan mempunyai kemampuan bioaktif sebagai bahan antibakteri (Rohaeti et al. 2010). Rhizophora mucronata mengandung senyawa metabolit skunder seperti tanin, senyawa fenolat, klorofil, karotenoid dan alkaloid. Buahnya dijadikan bahan makanan dan minuman, daun yang masih muda digunakan sebagai sayuran, kayu dan kulit kayu digunakan sebagai bahan penyamak (tanning) dan zat warna, air rebusan kayu (ekstrak) dapat digunakan sebagai obat pelangsing, antidiare dan antimuntah (Abidin, Halim, dan Me 2013). Rofik dan Riwayati (2013), menyebutkan bahwa tumbuhan api-api (Avicennia marina) dimanfaatkan sebagai bioformalin atau pengawet alami yang berasal dari alam oleh masyarakat nelayan, dari daun tumbuhan api-api mengandung setidaknya empat senyawa yang memiliki sifat mengawetkan. Keempat senyawa itu adalah saponin, tanin, alkaloid dan formalin. Senyawasenyawa tersebut merupakan rangkaian senyawa

yang

mencegah 
perkembangan bakteri pembusuk atau disebut juga dengan antibakteri.

Komponen fitokimia dapat diekstrak menggunakan berbagai pelarut tergantung senyawa targetnya. Jenis pelarut berperan penting dalam ketepatan proses ekstraksi komponen fitokimia. Pelarut seperti air, methanol, acetone murni dan larutan acetone 80\% dalam air mempunyai kemampuan yang berbeda dalam mengekstraksi komponen fitokimia. Pelarut jenis polar sepert air dan methanol dapat mengekstraksi senyawa polifenol lebih banyak (Thouri et al. 2017). Pelarut methanol dilanjutkan dengan pelarut etil asetat efektif dapat melarutkan quersetin, quercetin, kaempferol, cyanidin (Yuniarti et al. 2018). Namun ekstraksi pelarut organik, terutama aseton, heksane dan lain-lain, mempunyai kelemahan seperti bahan pelarut yang non-renewable, berbasis petroleum-based, dan diduga berbahaya untuk kesehatan dan lingkungan. Demikian pula pelarut polar seperti methanol dan ethanol perlu dipertimbangkan keamanan pangannya. Air merupakan salah satu jenis pelarut bahan fitokimia yang paling aman, greenest solvent, murah, ramah lingkungan, tidak toksik, tidak mudah terbakar (Chemat et al. 2019). Air dapat mengekstrak komponen fitokimia seperti terpenoids, saponins and tannins
(Fransina, Tanasale, dan Latupeirissa 2019). Tujuan penelitian adalah untuk membandingkan kandungan komponen fitokimia secara kualitatif buah mangrove sesudah dan sebelum proses ekstraksi menggunakan air.

\section{BAHAN DAN METODE}

Penelitian dilaksanakan pada Januari 2019 sampai dengan Maret 2019 dan bertempat di Kampus Balai Administrasi Pelatihan Perikanan Lapangan (BAPPL) Sekolah Tinggi Perikanan (STP) Serang untuk pengambilan sampel buah mangrove Laboratorium Biofarmaka IPB untuk pengujian fitokimia (kualitatif).

1. Pengambilan buah mangrove : Buah Mangrove (R. mucronata, A. marina, $R$. apiculata) diambil di kawasan Kampus Balai Administrasi Pelatihan Perikanan Lapangan (BAPPL) Sekolah Tinggi Perikanan (STP) Serang. Pengambilan sampel dilakukan di pagi hari (05.30 WIB 07.00 WIB). Sampel yang telah diambil langsung dicuci dan dimasukkan ke dalam coolbox yang telah berisi es. Sampel buah mangrove kemudian langsung didistribusikan ke Laboratorium Kimia Sekolah Tinggi Perikanan untuk diolah dan dibuat menjadi ekstrak buah mangrove. 
2. Pembuatan esktrak buah mangrove: ketiga jenis buah mangrove masingmasing dicuci bersih dan langsung dipotong-potong kecil / dicacah, kemudian dilakukan perendaman dengan asam sitrat $0,5 \%$ selama 10 menit dengan perbandingan $1: 3$ (b/b), setelah itu dilakukan perendaman dengan menggunakan akuades dengan perbandingan $1: 3$ (b/b) selama 3 hari. Setelah proses perendaman, dilakukan pengeringan selama 2 hari dengan menggunakan suhu ruang. Setelah kering, sampel dibentuk menjadi bubuk/simplisia. Simplisia kemudian dicampur dengan akuades dan disonikasi selama 30 menit untuk diambil filtratnya. Filtrat yang dihasilkan dimasukkan ke dalam botol kaca cokelat dan disimpan di dalam freezer hingga digunakan (Hardoko et al. 2018).

3. Uji Fitokimia Kualitatif meliputi (a) Uji Senyawa Alkaloid: Uji Dragendroff: Sampel (100 mg) dilarutkan dalam 10 $\mathrm{mL}$ pelarut. Sampel disaring, filtrat $(2$ $\mathrm{mL}$ ) ditambah dengan $1 \mathrm{~mL}$ reagen Dragendroff, Terbentuknya endapan merah menunjukkan adanya alkaloid (Tiwari et al. 2011). (b) Uji Mayer: Sampel (100 mg) dilarutkan dalam 10 $\mathrm{mL}$ pelarut. Sampel disaring, filtrat $(2$ $\mathrm{mL}$ ) ditambah dengan $1 \mathrm{~mL}$ reagen Meyer. Terbentuknya endapan kuning menunjukkan adanya alkaloid (Tiwari et al. 2011). (c) Uji senyawa flavonoid: Uji Reagen Alkalin: Sampel (100mg) dilarutkan dalam $10 \mathrm{~mL}$ pelarut, sampel disaring, filtrat $(2 \mathrm{~mL})$ ditambah beberapa tetes larutan $\mathrm{NaOH}$. Apabila terbentuk warna kuning dan memudar setelah ditambah dengan asam berarti positif mengandung flavonoid (Tiwari et al. 2011). (c) Uji Timbal Asetat: Sampel (100 mg) dilarutkan dalam $10 \mathrm{~mL}$ pelarut. Sampel disaring, filtrat $(2 \mathrm{~mL})$ dimasukkan dalam tabung reaksi, ditambahkan $1 \mathrm{~mL} \mathrm{~Pb}$ asetat $10 \%$ dan dikocok. Apabila terjadi perubahan warna menjadi cokelat kekuningan berarti positif mengandung flavonoid (Tiwari et al. 2011). (d) Uji senyawa saponin: Uji saponin dilakukan menurut Simes et al. (Sangi et al. 2008). Ekstrak sampel buah sebanyak 1 gram dimasukkan ke dalam tabung reaksi, kemudian ditambahkan akuades hingga seluruh sampel terendam, dididihkan selama 2-3 menit, dan selanjutnya didinginkan, kemudian dikocok kuat-kuat. Hasil positif ditunjukkan dengan terbentuknya buih yang stabil. (e) Uji senyawa tannin: Uji tanin dilakukan menurut Miranda (Sangi et al. 2008). Ekstrak sampel ditambah metanol sampai sampel terendam semuanya. Kemudian ditambahkan 2-3 tetes larutan $\mathrm{FeCl}_{3}$ 1\%. Hasil positif 
ditunjukkan dengan terbentuknya warna hitam kebiruan atau hijau. (f) Uji steroid: Satu $\mathrm{ml}$ ekstrak dilarutkan dalam $10 \mathrm{~mL}$ kloroform dan asam sulfur ditambahkan dengan volume yang sama. Lapisan atas yang berwarna merah dan lapisan asam sulfur yang berwarna kuning dengan disinari green fluorescence menunjukkan positif steroid (Trease dan Evans 1983). (g) Uji triterpenoid: Ekstrak 0,5 g ditambahkan $2 \mathrm{~mL}$ kloroform. asam sulfat (3 $\mathrm{mL})$ perlahan ditambahkan sampai terbentuk lapisan berwarna. Warna merah kecokelatan menunjukkan positif terpenoid (Trease dan Evans 1983).
HASIL DAN PEMBAHASAN

Hasil

Rhizophora mucronata

Uji fitokimia pada buah $R$. mucronata dilakukan untuk mengetahui jenis komponen fitokimia secara kualitatif baik pada buah mangrove sebelum diekstraksi dan setelah diektraksi. Uji fitokimia tersebut meliputi komponen flavonoid, alkaloid, tanin, saponin, kuinon dan steroid, dan triterpenoid Terdapat perbedaan hasil analisa fitokimia dimana buah mangrove $R$. mucronata masih mengandung tanin, namun pada ekstrak buah mangrove $R$. mucronata tidak mengandung tanin. Buah mangrove $R$. mucronata mengandung tanin, saponin dan steroid. Hasil pengujian fitokimia buah dan ekstrak buah $R$. mucronata dapat dilihat pada Tabel 1.

Tabel 1. Hasil Pengujian Fitokimia Buah dan Ekstrak Buah R. mucronata

\begin{tabular}{lll}
\hline \multicolumn{1}{c}{ Nama Sampel } & \multicolumn{1}{c}{ Parameter } & \multicolumn{1}{c}{ Hasil } \\
\hline Buah mangrove & Flavonoid & Negatif \\
& Alkaloid & Negatif \\
& Tanin & Positif \\
& Saponin & Positif \\
& Kuinon & Negatif \\
& Steroid & Positif \\
& Triterpenoid & Negatif \\
\hline Ekstrak buah mangrove & Flavonoid & Negatif \\
& Alkaloid & Negatif \\
& Tanin & Negatif \\
& Saponin & Positif \\
& Kuinon & Negatif \\
& Steroid & Positif \\
& Triterpenoid & Negatif \\
\hline
\end{tabular}


Tabel 2. Hasil Pengujian Fitokimia Buah dan Ekstrak Buah R. apiculata

\begin{tabular}{cll}
\hline \multicolumn{1}{c}{ Nama Sampel } & \multicolumn{1}{c}{ Parameter } & \multicolumn{1}{c}{ Hasil } \\
\hline Buah mangrove & Flavonoid & Negatif \\
& Alkaloid & Negatif \\
& Tanin & Positif \\
& Saponin & Positif \\
& Kuinon & Negatif \\
& Steroid & Positif \\
& Triterpenoid & Negatif \\
Ekstrak buah mangrove & Flavonoid & Negatif \\
& Alkaloid & Negatif \\
& Tanin & Positif \\
& Saponin & Positif \\
& Kuinon & Negatif \\
& Steroid & Positif \\
& Triterpenoid & Negatif \\
\hline
\end{tabular}

Tabel 3. Hasil Pengujian Fitokimia Buah dan Ekstrak Buah A. marina

\begin{tabular}{cll}
\hline \multicolumn{1}{c}{ Nama Sampel } & \multicolumn{1}{c}{ Parameter } & \multicolumn{1}{c}{ Hasil } \\
\hline Buah mangrove & Flavonoid & Negatif \\
& Alkaloid & Negatif \\
& Tanin & Positif \\
& Saponin & Positif \\
& Kuinon & Negatif \\
& Steroid & Positif \\
& Triterpenoid & Negatif \\
Ekstrak buah mangrove & Flavonoid & Negatif \\
& Alkaloid & Negatif \\
& Tanin & Positif \\
& Saponin & Positif \\
& Kuinon & Negatif \\
& Steroid & Positif \\
& Triterpenoid & Negatif \\
\hline
\end{tabular}

Rhizophora apiculata

Uji fitokimia pada buah mangrove $R$. apiculata dilakukan untuk mengetahui jenis komponen fitokimia secara kualitatif baik pada buah mangrove sebelum diekstraksi dan setelah diektraksi. Tidak terdapat perbedaan komponen fitokimia baik pada buah mangrove $R$. apiculata maupun ekstraknya. Buah mangrove $R$. apiculata dan ekstraknya mengandung tanin, saponin, dan steroid. Hasil pengujian fitokimia buah dan ekstrak 
buah $R$. apiculata dapat dilihat pada Tabel 2.

\section{Avicennia marina}

Uji fitokimia pada buah $A$. marina dilakukan untuk mengetahui jenis komponen fitokimia secara kualitatif baik pada buah mangrove sebelum diekstraksi dan setelah diektraksi. Tidak terdapat perbedaan komponen fitokimia baik pada buah mangrove $A$. marina maupun ekstraknya. Buah mangrove $A$. marina dan ekstraknya mengandung tanin, saponin dan steroid. Hasil pengujian fitokimia buah dan ekstrak buah $A$. marina dapat dilihat pada Tabel 3.

\section{Pembahasan}

Rhizophora mucronata

Pengujian fitokimia dengan pelarut akuades pada buah mangrove menunjukkan hasil positif pada senyawa tanin, saponin, steroid, sedangkan untuk ekstrak buah mangrove menunjukkan hasil positif pada senyawa saponin dan steroid. Hal ini menunjukkan bahwa kandungan tanin pada ekstrak buah $R$. mucronata tidak larut atau larut dalam jumlah yang sedikit pada saat perendaman dengan menggunakan asam sitrat dan pada perendaman dengan menggunakan akuades. Jumlah yang sedikit tersebut tidak dapat terdeteksi oleh reagen uji tanin. Hasil penelitian Hardoko et al. (2018) dengan pelarut akuades dan perlakuan perendaman dengan asam sitrat menunjukkan bahwa buah $R$. mucronata mengandung alkaloid, tanin, saponin, dan triterpenoid. Penelitian lain yaitu Purwaningsih, Handharyani, dan Sukarno (2013) pada buah mangrove tersebut, ekstraksi menggunakan pelarut methanol menunjukkan bahwa ekstrak buah mangrove mengandung senyawa flavonoid, tanin, saponin, dan kuinon.

Uji fitokimia pada tanaman merupakan uji screening awal dari eksplorasi tanaman yang mempunyai kemampuan bioaktif. Uji ini memerlukan ketepatan dan tingkat kepercayaan yang tinggi sehingga perlu memperhatikan standar analisa kimia, mutu reagen kimia serta kelarutannya bahan kimia tersebut. Ketepatan hasil uji kualitatif fitokimia akan menentukan langkah selanjutnya penelitian komponen bioaktif seperti penentuan uji kuantitatif komponen yang terdeteksi dari uji kualitatif, serta penentuan uji ekmampuan bioaktif ekstrak tanaman (Bandiola 2018).

\section{Rhizophora apiculata}

Hasil pengujian fitokimia pada buah dan ekstrak buah mangrove menunjukkan bahwa senyawa yang terkandung pada buah dan ekstrak buah mangrove tanin, saponin, dan steroid. Hal ini menunjukkan bahwa air dan asam 
sitrat dapat melarutkan senyawa tanin, saponin dan steroid mangrove Rhizophora apiculata. Penelitian kandungan fitokimia pada ekstrak daun $R$. apiculata dengan pelarut akuades yang dilakukan oleh (Susanti, Prayitno, dan Sarjito 2016) menunjukkan bahwa ekstrak daun mangrove mengandung saponin, tanin, flavonoid, steroid, dan terpenoid, hal ini sejalan dengan hasil penelitian Rochman dan Tukiran (2012) yang menunjukkan hasil senyawa yang terkandung pada ekstrak daun mangrove $R$. apiculata meliputi flavonoid, alkaloid, saponin, steroid dan tanin.

Screening komponen fitokimia yang dilakukan secara kualitatif dapat menggunakan beberapa metoda pada satu jenis analisa fitokimia untuk meyakinkan hasil analisa. Tetapi beberapa metode canggih dapat digunakan untuk digunakan untuk menentukan komponen fitokimia secara kualitatif maupun kuantitatif sekaligus tanpa melakukan beberapa tes individu (per senyawa fitokimia) (Silva, Abeysundara, dan Aponso 2017).

\section{Avicennia marina}

Hasil pengujian fitokimia pada buah dan ekstrak buah $A$. marina menunjukkan hasil bahwa senyawa yang terkandung dalam buah dan ekstrak buah mangrove yaitu tanin, saponin, dan steroid. Hasil analisis Pariansyah,
Herliany, dan Negara (2018), pada sampel buah mangrove dan ekstrak buah mangrove dengan pelarut akuades menunjukkan bahwa senyawa yang terkandung meliputi tanin, saponin, alkaloid, terpenoid, dan flavonoid. Kajian aktivitas antioksidan daun mangrove $A$. marina yang dilaksanakan oleh Jacoeb dan Purwaningsih (2011) dengan menggunakan pelarut etil asetat, methanol, dan heksan menunjukkan bahwa daun mangrove dengan pelarut etil asetat mengandung antioksidan tertinggi dibandingkan dengan pelarut methanol dan heksan. Hasil uji fitokimia daun $A$. marina mengandung senyawa steroid, flavonoid, dan benedict.

Pereaksi-pereaksi spesifik yang digunakan pada uji fitokimia, kebanyakan bersifat polar sehingga bisa berinteraksi dengan sampel mangrove berdasarkan prinsip 'like dissolve like' (Nuryanti dan Pursitasari 2014). Komponen fitokimia yang dianalisa pada buah mangrove antara lain flavonoid, alkaloid, tanin, saponin, kuinon, steroid, triterpenoid. Secara umum komponen yang teridentifikasi terdapat pada ketiga buah mangrove tersebut adalah tanin, saponin, dan steroid. Hasil ini menunjukkan bahwa air dapat digunakan untuk mengekstrak komponen fitokimia mangrove yaitu tanin, saponin, dan steroid. Identifikasi senyawa yang terdapat pada buah dan ekstrak buah 
mengrove mendapatkan hasil yang berbeda-beda. Priyanto (2012) menjelaskan bahwa, kadar alkaloid tumbuhan hijau, tidak semuanya menghasilkan kadar yang sama pada semua jaringan, hal ini dikarenakan setiap tahap pertumbuhan dan lokasi geografis yang berbeda-beda.

\section{SIMPULAN}

Hasil penelitian ini, didapatkan beberapa kesimpulan bahwa, kandungan fitokimia yang terdapat pada ekstrak buah $R$. mucronata adalah saponin dan steroid, sedangkan kandungan yang terdapat pada ekstrak buah $R$. apiculata dan $A$. marina adalah tannin, saponin, dan steroid. Penelitian selanjutnya dapat dilakukan uji fitokimia secara kuantitatif komponen fitokimia tannin, saponin, dan steroid dan pengujian kemampuan bioaktif komponen fitokimia ekstrak buah mangrove.

\section{PERSANTUNAN}

Biaya penelitian ini diperoleh dari DIPA Jurusan Penyuluhan Perikanan atas nama Tatty Yuniarti dan Noor Pitto Nio Lita.

\section{DAFTAR PUSTAKA}

A'in, Churun, Suryanti Suryanti, dan Bambang Sulardiono. 2018. "Kandungan Gizi pada Produk Olahan Mangrove (Krumang, Bomang, Simang) Produksi Kelompok Tani Ngudi Makaryo." INFO 19(1):24-33.

Abidin, Nurul Auni Zainal, Nurul Huda Abdul Halim, dan Ropisah Me. 2013. "Basic study of chemical constituents in Rhizophora species." in The Open Conference Proceedings Journal. Vol. 4.

Bandiola, Teresa May B. 2018. "Extraction and Qualitative Phytochemical Screening of Medicinal Plants: A Brief Summary." International Journal of Pharmacy 8(1):137-43.

Chemat, Farid, Maryline Abert Vian, Harish Karthikeyan Ravi, Boutheina Khadhraoui, Soukaina Hilali, Sandrine Perino, dan Annesylvie Fabiano Tixier. 2019. "Review of Alternative Solvents for Green Extraction of Food and Natural Products: Panorama , Principles ,." Molecules 24(3007):1-27. 
Fransina, Eirene G., Matheis F. J. D. P. Tanasale, dan Jolantje Latupeirissa. 2019. "Phytochemical screening of water extract of gayam ( Inocarpus edulis ) Bark and its amylase inhibitor activity assay Phytochemical screening of water extract of gayam ( Inocarpus edulis ) Bark and its amylase inhibitor activity assay." Hal. 7-14 in IOP Conference Series: Materials Science and Engineering 509.

Hardoko, Hardoko, Bambang Sasmito, Yunita Puspitasari, Yuyun Okviani, dan Yuniwaty Halim. 2018. "The effect of heating temperature on inhibitory activity of mangrove rhizophora mucronata fruit extract toward A-glucosidase." Asian Journal of Pharmaceutical and Clinical Research 11:237.

Jacoeb, Agoes Mardiono dan Sri Purwaningsih. 2011. "Anatomi, Komponen Bioaktif dan Aktivitas Antioksidan Daun Mangrove ApiApi (Avicennia marina)." Jurnal Pengolahan Hasil Perikanan Indonesia 14(2).

Khairun, Nisa Berawi dan Marini Desty. 2018. "Efektivitas Kulit Batang Bakau Minyak (Rhizopora apiculata) sebagai Antioksidan." Jurnal Agromedicine 5(1):412-17.
Mu, Honglei, Hangjun Chen, Xiangjun Fang, Jinlin Mao, dan Haiyan Gao. 2012. "Effect of cinnamaldehyde on melanosis and spoilage of Pacific white shrimp (Litopenaeus vannamei) during storage." Journal of the Science of Food and Agriculture 92(10):2177-82.

Nuryanti, Siti dan Dwi Pursitasari. 2014.

"UJI KUALITATIF SENYAWA METABOLIT SEKUNDER PADA DAUN PALADO ( Agave angustifolia ) YANG DIEKSTRAKSI DENGAN PELARUT AIR DAN ETANOL." Jurnal Akademika Kimia 3(3):16572.

Pariansyah, Ahmad, Nurlaila Ervina Herliany, dan Bertoka Fajar Surya Prawira Negara. 2018. "Aplikasi maserat buah mangrove Avicennia marina sebagai pengawet alami ikan nila segar." Acta Aquatica: Aquatic Sciences Journal 5(1):3644.

Priyanto, R. A. 2012. "Aktivitas Antioksidan Dan Komponen Bioaktif Pada Buah Bakau (Rhizophora Mucronata Lamk.) [skripsi]." Institut Pertanian Bogor. 
Purwaningsih, S., E. Handharyani, dan

A. Y. P. Sukarno. 2013. "Hepotoprotective effects extract ethanol of propagul mangrove (Rhizophora mucronata) in white rat strain Sprague Dawleyl induced carbon tetrachloride (CCl4)." in Maximizing Benefits and Minimizing Risks on Aquatic Products Processing: Blue Economy Approach. Bogor (ID).

Rochman, Ika Fatchur dan Tukiran. 2012. “Uji Bioaktivitas Ekstrak Kloroform Rhizophora apiculata terhadap Spodoptera littura sebagai Insektisida Nabati." UNESA Journal of Chemistry 1(1):33-39.

Rofik, Syaiful dan Indah Riwayati. 2013. "Pengaruh waktu terhadap kandungan glukosa pada reaksi hidrolisa enzimatis daun api-api (Avicennia alba) dengan menggunakan selulase." Prosiding SNST Fakultas Teknik 1(1).

Rohaeti, E., I. Batubara, A. Lieke, dan LK Darusman. 2010. "Potensi ekstrak Rhizophora sp. sebagai inhibitor tirosinase." Hal. 196-201 in Prosiding Seminar Nasional Sains III. Bogor (ID).
Sangi, Meiske, Max R. J. Runtuwene, Henry E. I. Simbala, dan Veronica M. A. Makang. 2008. "Analisis fitokimia tumbuhan obat di Kabupaten Minahasa Utara." Chemistry Progress 1(1):47-53.

Silva, Gusthinnadura Oshadie De, Achala Theekshana Abeysundara, dan Malamige Minoli Weroshana Aponso. 2017. "Extraction methods , qualitative and quantitative techniques for screening of phytochemicals from plants." American Journal of Essential Oils and Natural Products 5(2):29-32.

Sudjarwo, Giftania Wardani, Mahmiah Mahmiah, dan Mas'uliyatul Hukmiyah OM. 2017. "Kandungan Senyawa Metabolit Sekunder dari Fraksi Etil Asetat Kulit Batang Rhizopora mucronata L." Seminar Nasional Kelautan XII.

Susanti, Slamet Budi Prayitno, dan Sarjito. 2016. "Penggunaan Ekstrak Daun Bakau (Rhizophora apiculata) untuk Pengobatan Kepiting Bakau (Scylla serrate) yang Diinfeksi Bakteri Vibrio harveyi terhadap Kelulushidupan." Journal of Aquaculture Management and Technology 5(2):18-25. 
Thouri, Amira, Hassiba Chahdoura, Amira El Arem, Amel Omri Hichri, Rihab Ben Hassin, dan Lotfi Achour. 2017. "Effect of solvents extraction on phytochemical components and biological activities of Tunisian date seeds ( var . Korkobbi and Arechti )." BMC Complementary and Alternative Medicine 17(248):1-10.

Tiwari, Prashant, Bimlesh Kumar, Mandeep Kaur, Gurpreet Kaur, dan Harleen Kaur. 2011. "Phytochemical screening and extraction: a review." Internationale pharmaceutica sciencia 1(1):98106.

Trease, G. E. dan W. C. Evans. 1983. "Colchicum seed and corn." in Textbook of pharmacognosy. London (GB): Tindall and Co.

Yuniarti, Tatty, Sukarno, Nancy Dewi Yuliana, dan Slamet Budijanto. 2018. "Inhibition of Enzymatic Browning by Onion (Allium cepa L.): Investigation on Inhibitory Mechanism and Identification of Active Compounds." Current Research in Nutrition and Food Science Journal 6(3):770-80. 